\title{
Mukaiyama Aldol Reaction Catalyzed by a MOF-Based $\mathrm{Fe}^{3+}$ Complex
}
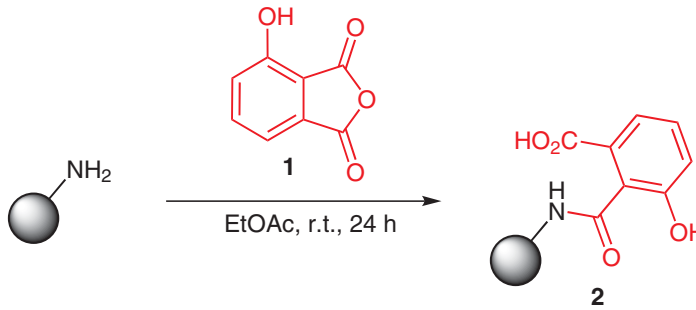

$\mathrm{Fe}(\mathrm{acac})_{3}, \mathrm{CHCl}_{3}$, r.t.

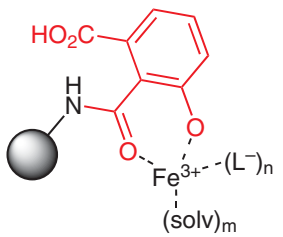

UMCM-1-AMFesa

UMCM-1- $\mathrm{NH}_{2}$

Mukaiyama aldol

reaction

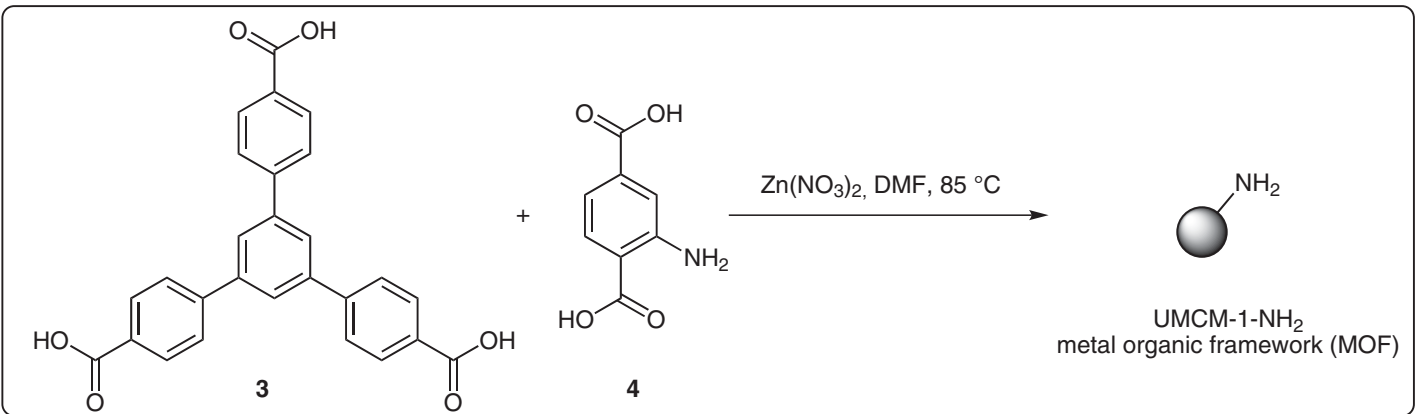

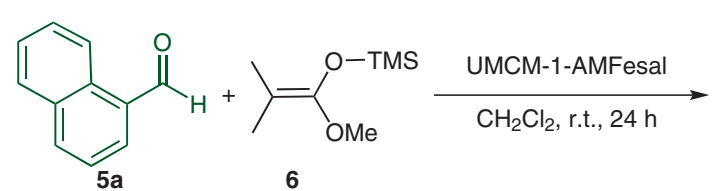

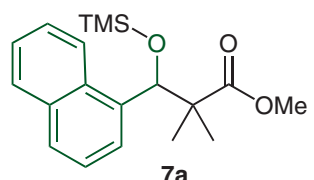

$7 a$<smiles>Cc1cc(C)c(C=O)c(C)c1</smiles><smiles>COC(OC)=C(C)C</smiles>

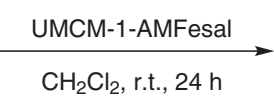

$5 b$<smiles>COC(=O)C(C)(C)C(OS(C)(=O)=O)c1c(C)cc(C)cc1C</smiles>

$7 b$
$70 \pm 11 \%$ yield ( $1^{\text {st }}$ cycle) $56 \pm 12 \%$ yield $\left(2^{\text {nd }}\right.$ cycle)

$52 \pm 12 \%$ yield ( $3^{\text {rd }}$ cycle) *average yield based on 4 trials

$53 \pm 18 \%$ yield ( $1^{\text {st }}$ cycle) $55 \pm 5 \%$ yield $\left(2^{\text {nd }}\right.$ cycle $)$ $65 \pm 8 \%$ yield ( $3^{\text {rd }}$ cycle) *average yield based on 3 trials
Significance: A metal-organic framework (MOF) based $\mathrm{Fe}^{3+}$ catalyst was developed and applied to the Mukaiyama aldol reaction. Thus, the MOFbased $\mathrm{Fe}^{3+}$, UMCM-1-AMFesal, was prepared by condensation of MOF composite UMCM-1- $\mathrm{NH}_{2}$ with acid anhydride $\mathbf{1}$ followed by metalation with $\mathrm{Fe}(\mathrm{acac})_{3}$. The Mukaiyama aldol reaction of aldehydes $\mathbf{5 a} \mathbf{a}, \mathbf{b}$ and a silyl ketene acetal $\mathbf{6}$ was carried out with UMCM-1-AMFesal (0.1 mol\% $\mathrm{Fe}$ ) to give the corresponding $\beta$-hydroxy esters in $70 \pm 11 \%$ yield $(\mathbf{7 a})$ and $53 \pm 18 \%$ yield $(\mathbf{7 b})$. The catalyst was reused twice without loss of catalytic activity.
Comment: The preparation of UMCM-1-NH (University of Michigan Crystalline Material-1$\mathrm{NH}_{2}$ ), consisting of $4,4^{\prime}, 4^{\prime \prime}$-benzene-1,3,5-triyltribenzoate (3), 2-amino-1,4-benzenedicarboxylic acid (4), and $\mathrm{Zn}\left(\mathrm{NO}_{3}\right)_{2}$, was previously reported (Inorg. Chem. 2009, 48, 296). UMCM-1 was originally prepared by Matzger and co-workers (Angew. Chem. Int. Ed. 2008, 4, 677).

SYNFACTS Contributors: Yasuhiro Uozumi, Yoichi M. A. Yamada, Toshihiro Watanabe 